\title{
CHANGE MANAGEMENT: DAMPAK PERUBAHAN DENGAN ADANYA IMPLEMENTASI IT
}

\author{
Iwan Kurniawan Widjaya \\ Jurusan Komputerisasi Akuntansi, Fakultas Ilmu Komputer, Bina Nusantara University \\ Jln. KH Syahdan No 9, Palmerah, Jakarta Barat 11480 \\ iwkoo2005@yahoo.com
}

\begin{abstract}
Technology improvement has brought much changes in how businesses and organizations have to run properly in global competitions. But the most important thing is the changing in organizations and people who will operate with the integrations systems. Resistance always happens in every implementations and it will be the main problems in every company. In this paper, it will be explored more in details about the cause and effect from the changes that will happens before and after the implementations, including how to utilize the result of the implementations in order to get the benefits for the business. Another important things are including the strategy and planning of changes that should be effectively implemented and given the maximum contributions to support the future development and synergy with business planning. This paper is also given the guidance about how to act and do some preventive actions in managing better ways in setting up the planning of changes in implementations of Information Technology and systems in the best ways.
\end{abstract}

Keywords: information technology, system, business, implementation, changes.

\begin{abstract}
ABSTRAK
Kemajuan teknologi telah membawa banyak perubahan dalam bisnis dan organisasi untuk bersaing dalam kompetisi global. Tetapi, hal paling terpenting adalah perubahan dalam organisasi dan sumber daya manusia yang akan mengoperasikan sistem terintegrasi tersebut. Hambatan selalu terjadi dalam tiap implementasi dan akan menjadi permasalahan utama dalam setiap perusahaan. Paper ini akan mengeksplorasi detil sebab dan akibat sebuah perubahan yang mungkin terjadi sebelum dan setelah implementasi, termasuk bagaimana untuk memanfaatkan hasil dari implementasi untuk mendapatkan laba perusahaan. Hal penting lainnya yaitu strategi dan perencanaan perubahaan yang harus bisa terimplementasikan dengan efektif dan memberikan kontribusi maksimal dalam mendukung perkembangan dan sinergi dalam rencana bisnis ke depan. Paper ini juga memberikan petunjuk tentang bagaimana mengatur cara-cara yang baik dalam menetapkan rencana perubahan dengan implementasinya dalam teknologi informasi dan sistem.
\end{abstract}

Kata kunci: teknologi informasi, sistem, bisnis, implementasi, perubahan. 


\section{PENDAHULUAN}

Nothing in the world can take the place of persistence. Talent will not; nothing is more common than unsuccessful men with talent. Genius will not; unrewarded genius is almost a proverb. Education will not; the world is full of educated derelicts. Persistence and determination alone are omnipotent.

Bila kita melihat kata perubahan mungkin kita tidak bisa menyangkal bahwa kita harus dan selalu berubah. Karena perubahan memberikan dampak terhadap semua aspek yang ada di dalam maupun di luar suatu organisasi atau perusahaan. Tetapi sampai seberapa jauh perubahan tersebut terjadi dan dampak yang diakibatkan dari perubahan tersebut. TI atau Information Technology yang terus berkembang dewasa ini dan sebagai alat dalam membantu bisnis, telah memberikan dampak yang sangat besar serta membawa arus perubahan di dalam suatu organisasi atau perusahaan, baik sektor swasta maupun pemerintah. Sebagai contoh bila kita melihat dalam dunia perbankan, 20 tahun yang lalu teknologi kartu dan ATM merupakan barang atau produk aneh dalam dunia bisnis dan transaksi keuangan. Sedangkan saat ini penggunaannya sudah merupakan suatu keharusan dan umum bagi pelayanan perbankan dewasa ini. Bahkan perkembangan mobile banking telah menunjukkan suatu terobosan baru dari pemanfaatan teknologi informasi.

\section{PEMBAHASAN}

Untuk melihat lebih jauh langkah yang perlu dilakukan oleh para profesional di posisi manajemen yang ingin melakukan pembedahan dan evaluasi mengenai bagaimana implementasi IT dapat dilakukan dan dengan lebih berhati-hati termasuk melihat berbagai aspek yang saling terkait, perlu kiranya kita mengkaji strategi yang efektif dan efisien. Menurut hasil survei, beberapa masalah utama yang sering dihadapi oleh manajemen di dalam penerapan dan implementasi Teknologi Informasi meliputi beberapa masalah serius yang dirangkum dalam cakupan seperti keangkuhan, penundaan, menolak perubahan, CEO atau manajer yang tidak kompeten, buruknya kualitas karyawan, dan penyimpangan internal kontrol.

\section{Keangkuhan}

Sikap ini muncul karena keberhasilan yang telah diraih perusahaan atau organisasi sebelumnya dan sengaja bersikap acuh atau menolak mengakui perubahan yang mencolok yang terjadi di lingkungan pasar, persaingan dan lain-lainnya. Sikap ini dapat menyebabkan kegagalan dalam membuat perencanaan bagi keseluruhan strategi penerapan IT atau salah menafsirkan lingkungan pangsa pasar. Perasaan superioritas bisa terkadang meresap dan menjadi suatu budaya perusahaan secara keseluruhan.

\section{Penundaan}

Sikap ini sering dilakukan oleh suatu organisasi atau perusahaan yang menganggap bahwa usaha untuk perubahan dirasakan belum perlu dan bukan menjadi prioritas untuk dijalankan. Hal ini terjadi karena tidak ada satupun usaha dan adanya suatu sikap keragu-raguan, takut gagal dalam melakukan suatu implementasi.

\section{Menolak Perubahan}

Hal ini disebabkan oleh suatu kebiasaan atau stereotipe yang menciptakan hambatan seperti perusahaan yang menerima sindrom cetakan. Sayangnya cetakan tersebut mungkin sudah ketinggalan 
zaman atau tidak relevan lagi. Ide-ide baru yang bersifat inovasi, kreativitas yang akan dilakukan ditolak karena tidak bersifat konvensional, radikal dan tidak layak untuk dilakukan. Kondisi yang demikian sering berakibat pada hilangnya kesempatan untuk melakukan terobosan besar perusahaan.

\section{CEO Atau Manajer yang Tidak Kompeten}

Hal ini terjadi karena perusahaan mempekerjakan orang yang salah, tidak kompeten, kurang berpengalaman dan tidak memiliki pengalaman di dalam menjalankan operasional yang terkait dengan implementasi strategi bisnis yang bersinergi dengan penerapan teknologi informasi. Hal ini berakibat pada melesetnya suatu kesempatan perusahaan untuk memperoleh kesempatan dan mendapatkan celah untuk pengembangan usaha dengan bantuan teknologi informasi.

\section{Buruknya Kualitas Karyawan}

Hal ini akan sangat mengganggu operasional dan implementasi Teknologi Informasi di dalam suatu perusahaan atau organisasi. Buruknya kualitas eksekutif bisa mengakibatkan menyimpangnya implementasi Teknologi Informasi dari sisi sasaran dan strategi perusahaan secara keseluruhan. Selain itu, pegawai yang tidak terlatih dengan baik atau pegawai yang tidak sesuai dapat berpengaruh buruk bagi bisnis dan citra perusahaan secara keseluruhan. Hal ini akan terlihat dari buruknya pelayanan ke konsumen, penurunan penjualan dan menipisnya pangsa pasar.

\section{Penyimpangan Internal Kontrol}

Sikap acuh dari manajemen terhadap internal kontrol akan berakibat fatal dan akan berdampak terhadap kondisi keuangan. Peranan IT dalam membantu perusahaan untuk meningkatkan kinerja sistem informasi dan pelaporan dari sisi keuangan akan menjadi pemicu atas peningkatkan pengembangan bisnis perusahaan di masa mendatang. Masalah-masalah yang muncul sebagai akibat dari kegagalan dalam melaporkan kesalahan-kesalahan, pencurian bahkan penyelewengan. Dalam beberapa kasus, penyimpangan yang serius akan berakibat pada pencabutan izin usaha dan bahkan runtuhnya seluruh perusahaan. Manajemen puncak harus memperjelas kerangka strategi yang harus dilakukan, penulis juga sedikit berbagi pengalaman yang diuraikan dalam gambar pemetaan secara sederhana mengenai apabila kita mau memulai dan melihat bagaimana langkah awal yang perlu dilakukan agar kita dapat melihat dengan jelas kondisi di dalam organisasi sehubungan dengan implementasi IT yang akan kita lakukan atau mulai. Dengan kondisi permasalahan yang ada diatas tidak semua teknologi dan implementasi TI dapat membantu untuk menyelesaikan semuanya, tetapi secara umum bahwa strategi analisa pemetaan implementasi IT yang terjadi di dalam suatu organisasi atau perusahaan dapat dijabarkan dalam kerangka dan gambar berikut ini.

\section{Empat Komponen Penting dari Implementasi}

Pemetaan diatas jelas sangat membantu bagi para eksekutif senior maupun muda yang membutuhkan suatu arahan atau petunjuk mengenai apa yang perlu dilakukan di dalam memperbaiki kondisi arus informasi dan Teknologi informasi yang ada di perusahaan. Saat ini perubahan dan globalisasi teknologi menjadi suatu keharusan bila suatu organisasi atau perusahaan mau berkompetisi secara global di pasar internasional dan bahkan lebih dari itu peranan komitmen dari manajemen puncak memberikan andil yang sangat besar terhadap kesuksesan yang akan dicapai. Tetapi ada hal yang perlu diingat bahwa penggunaan dan perubahan yang tepat guna serta terukur yang dapat membawa perbaikan dan manfaat bagi perkembangan bisnis bagi suatu organisasi atau perusahaan. Bila ditinjau lebih dalam terutama dari sisi kita, sebagai karyawan, sebagai profesional dalam bidang apapun yang kita geluti dan tekuni sehari-hari , apakah yang sesungguhnya kita hadapi sebagai suatu ruang lingkup dan lingkungan yang kita jalani sehari-hari di dalam operasional perusahaan? Tingkat kesibukan di tiap-tiap bagian yang terlibat dalam proses operasional telah menjadikan suatu lingkaran 
dan siklus yang menyebabkan kita terlarut dalam proses kebiasaan dan rutinitas di dalam bekerja. Perubahan pola kerja dengan masuknya teknologi informasi akan memberikan suatu dampak yang cukup besar.

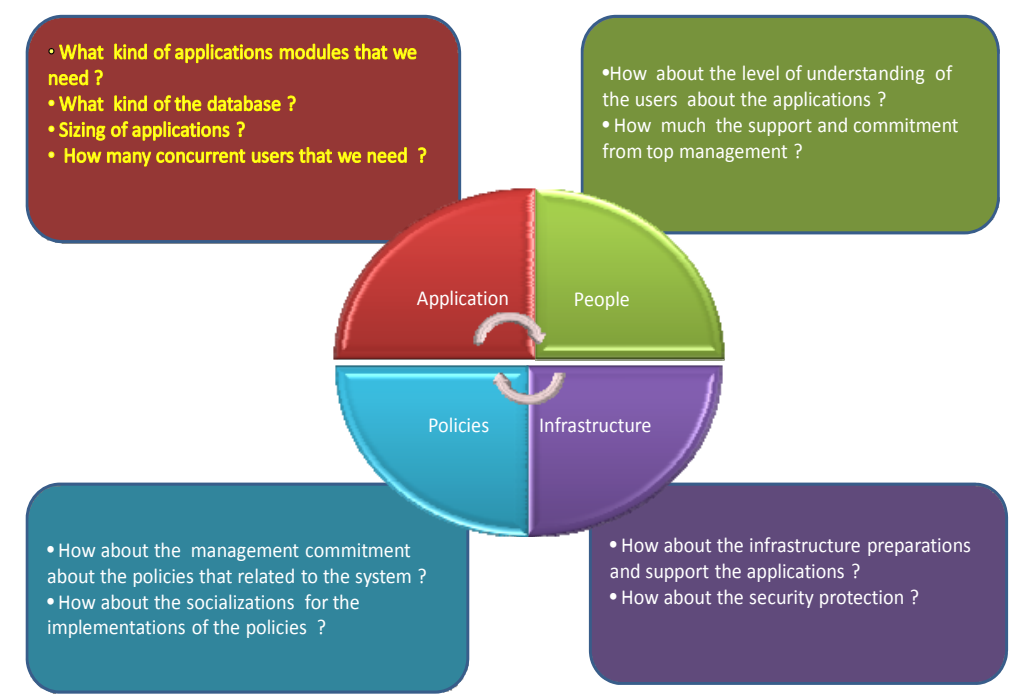

Gambar 1 Pemetaan untuk Implementasi Information Technology

Kita terkadang sulit untuk menyesuaikan keadaan tersebut apalagi bila perubahan tersebut memberikan perubahan dari sisi kuantitas kerja kita. Gambar pemetaan untuk Implementasi Information Technology diatas, menjelaskan secara sederhana mengenai bagaimana eksekutif puncak dapat melihat serta mendiagnosa organisasi atau perusahaannya secara obyektif dan mengambil langkah yang tepat dalam mengatasi masalah yang ada di dalam organisasi atau perusahaan yang dipimpinnya. Secara sederhana bahwa implementasi IT melibatkan 4 faktor utama yang menjadi komponen inti yang meliputi: (1) applications, sistem dan aplikasi yang akan diterapkan di dalam suatu organisasi di dalam perusahaan, baik yang diperoleh dari outsourcing maupun dibuat secara inhouse development; (2) people, meliputi pemakai atau user dan juga business owner dari suatu proses di dalam organisasi atau perusahaan serta team yang memimpin dan memonitor proyek IT; (3) policies, meliputi peraturan dan kebijakan yang berdampak terhadap proses yang ada di dalam suatu organisasi. Policy ini ditentukan oleh manajemen puncak berdasarkan suatu evaluasi secara berkala dan konsisten; (4) infrastructure, meliputi perangkat dan kerangka jaringan komunikasi yang mendukung terlaksananya implementasi dari sistem informasi dan aplikasi.

Setelah kita melihat pemetaan diatas secara jelas maka kita dapat mengkaitkan hubungan antara kinerja suatu perusahaan dengan pemetaan implementasi IT diatas. Dari gambar dibawah ini dapat dijelaskan mengenai ruang lingkup dari bagaimana kita dapat meningkatkan kesejahteraan serta kepuasan dari karyawan dan organisasi secara umum. Serta siklus yang terjadi dari dampak implementasi Teknologi Informasi yang dapat memberikan suatu peningkatan kepuasan dari Karyawan. Hal ini tentunya sangat terkait dengan kualitas dari produktivitas kita sendiri dan bagaimana kontribusi kita ke institusi atau perusahaan dimana kita bekerja dapat berjalan dengan baik. Gambar berikut ini menjelaskan mengenai siklus yang terjadi di dalam perusahaan yang meliputi interaksi secara internal yaitu karyawan dengan organisasi dan organisasi dengan eksternal yang dalam hal ini pelanggan. 


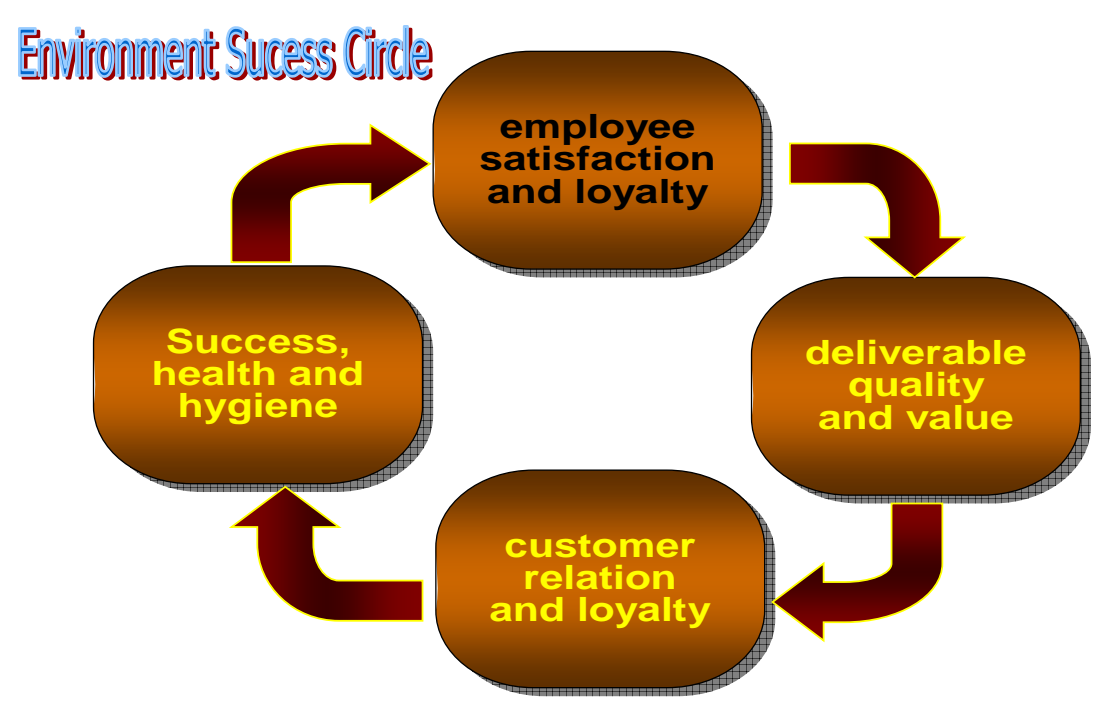

Gambar 2 Siklus dari tingkat kesuksesan di dalam lingkungan

Siklus diatas mencerminkan seberapa jauh dan mampu tingkat pencapaian kesuksesan lingkungan dapat dicapai. Semua orang pada hakekatnya ingin mencapai suatu tingkat kepuasan yang setinggi-tingginya baik ia sebagai karyawan maupun dari sisi pengusaha atau pemilik. Bagaimana siklus kesuksesan di dalam lingkungan bekerja dapat tercapai ? Siklus yang dapat dikaji dari gambar diatas menjelaskan bagaimana kepuasan dan loyalitas akan memberikan kontribusi ke dalam kualitas kerja dan memberikan nilai tambah bagi organisasi serta meningkatkan tingkat loyalitas dan hubungan baik dengan pelanggan. Hal tersebut akan berlanjut secara berkesinambungan dengan pihak eksternal yang menerima manfaat dari hasil yang baik dari organisasi ke pelanggan, hubungan dengan pelanggan akan menjadi lebih baik dan loyalitas semakin tinggi. Wujud dari kesinambungan proses ini akan meningkatkan kinerja dan kemampuan perusahan untuk dapat membuat suatu keunggulan secara kompetitif di dalam persaingan global. Siklus tersebut juga berlanjut sehingga tingkat kesuksesan dan manfaat yang akan diterima akan terjadi di kedua belah pihak. Memang kelihatannya sangat idealis tetapi realitas yang kita lihat dari perusahaan-perusahaan besar yang telah merealisasikan konsep diatas mempunyai nilai kompetitif dalam persaingan bisnis yang kuat dan dapat bertahan di dalam era globalisasi ini.

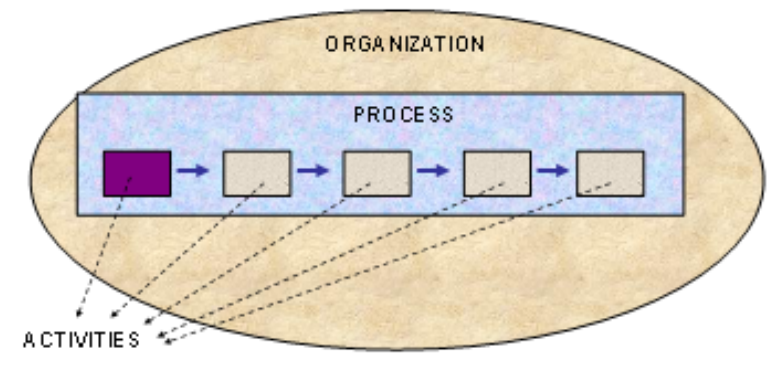

Gambar 3 Organizations and Activities in process Flow

Sekarang mungkin kita akan melihat lebih jauh bagaimana siklus tersebut dapat terus berlanjut dan berjalan secara harmonis. Pada hakekatnya suatu organisasi akan berjalan dengan baik apabila setiap proses dan aktivitas di dalamnya dapat dipetakan dengan jelas sehingga setiap proses dapat diukur. Kenyataan yang ada bahwa perubahan dan persaingan bisnis telah membuat kehidupan yang harmonis menjadi sangat mahal. Ditambah lagi teknologi yang semakin berkembang dan mereka saling berlomba-lomba, menyebabkan tingkat kecepatan perubahan yang terjadi di organisasi menjadi 
sangat cepat dan mungkin bisa tertinggal dari yang lainnya. Hal ini kita sadari maupun tidak kita sadari baik langsung maupun secara tidak langsung.

\section{Kerangka Dari Perubahan Manajemen Internal}

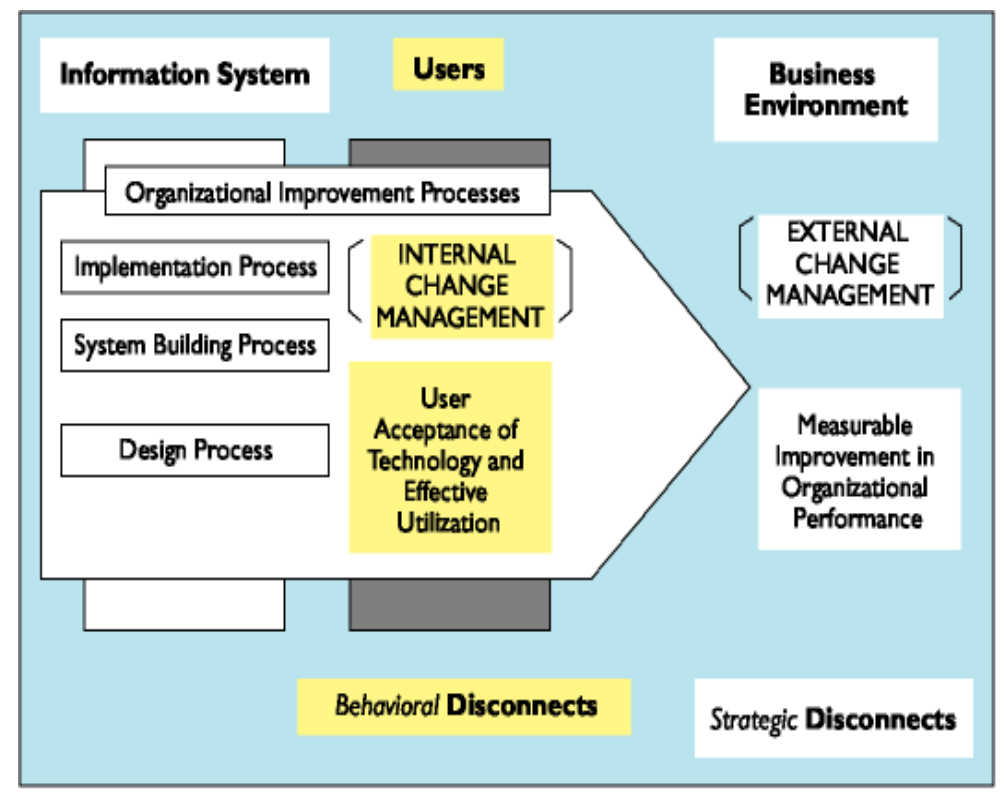

Gambar 4 Kerangka internal change management Dari: Malhotra \& Galetta (2004)

Sebagai gambaran dampak yang muncul dengan berkembangnya Sistem Informasi dan Teknologi terlihat dalam ilustrasi dibawah ini bahwa bagaimana user atau pemakai dan lingkungan bisnis terpengaruh dengan transformasi dan implementasi Teknologi Informasi di suatu organisasi. Gambar dibawah ini juga menjelaskan bagaimana tingkat perubahan manajemen yang terjadi dengan adanya dampak penerapan sistem informasi dan lingkungan bisnis yang terkait.

Ketika efektifitas dari pemanfaatan teknologi informasi tidak terjadi dan sistem tidak memberikan dampak perubahan dan perbaikan terhadap bisnis, faktor non teknis menjadi titik utama yang harus dievaluasi. Bentuk faktor non teknis tersebut antara lain dan tidak bukan adalah human factor atau individu yang ada di dalam organisasi tersebut. Bagaimana ini bisa terjadi ? Ketidakcocokan antara apa yang diharapkan dari penerapan teknologi informasi akan membentuk proses dan perubahan di dalam organisasi telah mendorong suatu perubahan perilaku dari individu yang ada di dalam organisasi tersebut. Dampak lebih lanjut yang terjadi adalah Strategi perusahaan atau organisasi akan berubah dan terpengaruh baik secara langsung maupun tidak langsung. Sebenarnya hal tersebut tidak perlu terjadi, tetapi hal ini seringkali terjadi. Mengapa demikian? Banyak perusahaan tidak melakukan sinergi secara konsisten antara kebutuhan bisnis dengan teknologi dan yang tidak kalah pentingya adalah kesiapan sumber daya manusia yang terkait, yang akan menjalankan teknologi tersebut. Sehingga banyak investasi IT menjadi gagal dan bahkan gagal total karena manfaat yang diperoleh tidak sesuai dengan apa yang diharapkan sejak saat awal. Dampak perubahan yang disebabkan oleh teknologi harus sedini mungkin diantisipasi dan dipersiapkan baik dari sisi mental maupun prosedur secara menyeluruh. Tanpa antisipasi yang baik maka pengukuran atas kinerja implementasi IT, perbaikan di dalam organisasi, efisiensi dan efektifitas tidak akan tercapai. Untuk mencapai kesuksesan di dalam menerapkan suatu perubahan tentunya kita harus mampu mendeteksi secara psikologis aspek-aspek emosional yang mungkin terjadi dan sampai pada taraf mana perubahan tersebut memberikan dampak terhadap individu dan organisasi yang terkait 
dengan perubahan yang akan dilaksanakan dan yang diimplementasikan. User acceptance of technology and effective utilizations merupakan target utama setiap penerapan dari implementasi teknologi informasi yang efektif di dalam suatu organisasi. Tanpa adanya penerimaan dan pemanfaatan secara efektif dari para pemakai suatu implementasi tidak dapat dikatakan berhasil secara optimal. Untuk mencapai target tersebut peranan dari internal change management memberikan kontribusi yang besar terhadap tingkat kesuksesan yang akan dicapai dari hasil implementasi TI bagi suatu organisasi atau perusahaan. Pembahasan mengenai strategi perubahan manajemen atau change management dibahas lebih lanjut dalam bab berikut dalam tulisan ini. Berikut ini merupakan kerangka siklus tingkat emosi dari internal change management secara psikologis yang muncul sebagai dampak dari perubahan yang akan dijalankan di dalam suatu organisasi.

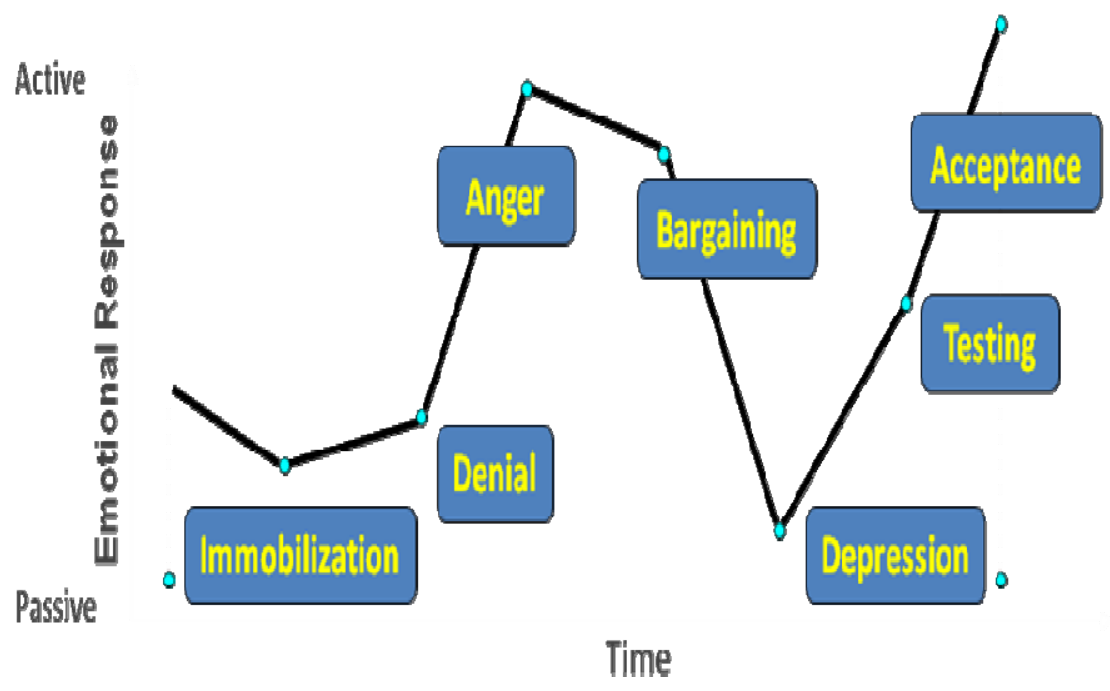

Gambar 5 Behavior of level changes

Penjelasan dari Gambar 5 merupakan suatu siklus perubahan perilaku dari individu atau organisasi yang disebabkan oleh reaksi terhadap proses perubahan yang dialami oleh individu serta melalui beberapa fase tingkat emosi yang timbul dengan dampak yang terjadi dari sisi waktu dan intensitas atau kekuatan emosi yang terjadi. Siklus tersebut sangat bervariasi dari sisi waktu, intensitas dan kemampuan masing-masing individu di dalam menerima respon yang dialami di dalam interaksinya terhadap team pada suatu organisasi atau perusahaan.

Proses perubahan perilaku yang terjadi dari suatu organisasi atau individu yang terkait dengan proses manajemen perubahan dapat diuraikan dalam penjelasan berikut ini, hal ini dimulai dari prosesproses serta tahapan-tahapan yaitu immobilization, denial, anger, bargaining, depression, testing, acceptance.

\section{Immobilization}

Ketika suatu proses perubahan akan diterapkan dampak dari emosi dan perilaku yang muncul dari suatu organisasi atau individu yang terlibat adalah kondisi yang tidak dapat bekerja sama atau ketidak teraturan dan sulit untuk diorganisir apabila sudut pandang dan pemahaman individu menjadi berbeda dengan apa yang diinginkan oleh manajemen puncak. Pada tahapan ini perilaku dari suatu organisasi atau individu cenderung bersifat pasif. Mereka lebih cenderung untuk menunggu daripada untuk bersikap proaktif. 


\section{Denial}

Seiring dengan proses waktu tahapan berikutnya setelah immobilization adalah proses penolakan atau denial. Mengapa hal ini terjadi ? Penolakan muncul karena perubahan yang akan dilakukan memberikan suatu dampak yang bisa merubah kebiasaan, kepentingan dari sekelompok individu di dalam suatu organisasi. Terutama terjadi apabila perubahan tersebut memberikan suatu kerugian bagi individu dan juga mengancam keamanan kerja dari seseorang. Penolakan ini dapat berwujud ketidakpatuhan, marah, pola perilaku yang tidak sehat dan bahkan bisa membawa kearah sabotase secara materi. Pada tahapan ini bila team perubah tidak dapat mengendalikan dan menyusun suatu strategi dengan baik maka akan berlanjut ke tahapan yang bersifat destruktif, hal ini diuraikan dalam pembahasan berikut ini.

\section{Anger}

Atau kemarahan, proses pola perubahan perilaku dari emosi yang mendalam yang dikeluarkan dalam wujud negatif. Kemarahan dari individu bisa memicu ke dalam kemarahan dari suatu kelompok individu di dalam suatu organisasi. Dalam tahapan ini pola perilaku dari individu akan lebih sulit dikendalikan dan pendekatan yang intensif secara psikologis harus dilakukan dalam memberikan suatu pengertian dari makna perubahan yang akan dilakukan dari suatu organisasi atau individu. Apabila tahapan ini bisa dilalui oleh agen perubah maka proses negosiasi atau bargaining, hal ini merupakan langkah yang tepat untuk mencapai titik temu dari target perubahan yang dikehendaki oleh suatu organisasi dengan tujuan dari individu itu sendiri. Pada fase ini merupakan fase yang cukup kritis dan bisa berakhir pada suatu kondisi win or lose. Hal ini berarti bahwa bila manajemen mengambil langkah yang tegas akan berakibat pada kerugian di salah satu pihak. Untuk meminimalisasi hal tersebut. Peranan dan keahlian agen perubah untuk menyusun suatu strategi pendekatan merupakan kunci utama dari keberhasilan implementasi Teknologi Informasi.

\section{Bargaining}

atau sering disebut proses negosiasi, hal ini sering dilakukan dalam setiap penerapan suatu perubahan yang diwujudkan dalam perubahan sistem atau peraturan di dalam suatu organisasi. Tahapan ini dilakukan dengan tujuan untuk mengurangi tingkat konflik yang terjadi di dalam suatu organisasi atau antar organisasi. Banyak konflik yang terjadi yang disebabkan oleh perubahan manajemen dapat dihindari dengan melakukan proses negosiasi? Tentunya kemampuan diplomasi dari team perubah merupakan kunci utama dari tingkat keberhasilan yang akan dicapai. Apabila tahapan ini dapat dicapai maka tingkat penerimaan dari perubahan yang dikehendaki dari setiap individu atau organisasi akan berhasil.

\section{Depression}

Suatu kondisi dimana tingkat emosi dari individu atau organisasi mencapai puncak atau tingkatan terbawah dari dampak perubahan yang terjadi. Kondisi ini terjadi apabila perubahan yang dilakukan berdampak secara radikal dan mendasar sehingga menyangkut tingkat emosi yang berubah secara radikal. Dalam kondisi yang sering kita ketahui di dalam sistem perekonomian hal ini merupakan titik lemah yang akan terjadi.

\section{Testing}

Pengujian merupakan langkah yang efektif untuk membuktikan bahwa memang perubahan perlu dilakukan. Apabila pengujian ini berhasil maka akan menghasilkan 2 kemungkinan yang akan terjadi terhadap individu atau suatu organisasi yaitu setiap individu atau organisasi akan bertambah yakin bahwa perubahan tersebut layak dilakukan. Tentunya dibutuhkan suatu perencanaan yang matang agar hasil yang dikehendaki dapat tercapai. Namun sebaliknya bila pengujian ini gagal juga 
bisa berakibat fatal yaitu bisa kembali ke tahapan penolakan atau ketidakpercayaan terhadap perubahan yang diharapkan terjadi.

\section{Acceptance}

Menerima perubahan. Adakalanya setiap langkah penerapan perubahan dapat diterima dengan baik dan mudah dari setiap individu atau organisasi. Hal ini terjadi karena tingkat pemahaman yang dimiliki sejalan dan seiring dengan apa yang dikehendaki oleh manajemen puncak atau pimpinan. Tetapi hal yang sering terjadi bukanlah demikian adanya, banyak hal yang terjadi bahkan sebaliknya. Pendekatan psikologi merupakan pendekatan yang efektif dengan didasari oleh landasan pemikiran, tujuan dan strategi yang tepat. Sering orang mengatakan bahwa untuk melakukan perubahan dan mencapai sasaran yang dikehendaki dibutuhkan suatu cara yang berbeda, meskipun untuk tujuan yang sama. Perlu diingat bahwa faktor - faktor dari kemampuan individu dalam suatu organisasi sangat berperan besar dalam melakukan perubahan. Setelah suatu konsep perubahan tersebut diterima, tentunya kita perlu membuktikan bahwa perubahan tersebut akan memberikan dampak yang baik. Untuk itu perlu dilakukan pengujian terhadap konsep perubahan yang dikehendaki secara berkala dan berkesinambungan.

Semua proses diatas tentunya membutuhkan waktu dan lama proses yang dibutuhkan sangat bervariatif, hal ini sangat bergantung dari tingkat komitmen dan dukungan dari manajemen puncak, kemampuan dari team perubah itu sendiri, strategi yang dilakukan, individu atau organisasi yang akan dirubah, serta evaluasi secara berkala terhadap perubahan yang dikehendaki.

Hal-hal diatas belumlah cukup, karena selain faktor internal, faktor ekternal juga berperanan penting. Untuk itu perlunya suatu kesamaan nilai, tujuan, kepentingan dan tujuan seperti yang diilustrasikan dalam gambar berikut ini mengenai bagaimana proses Person fit in Organizations memegang peranan yang sangat penting.

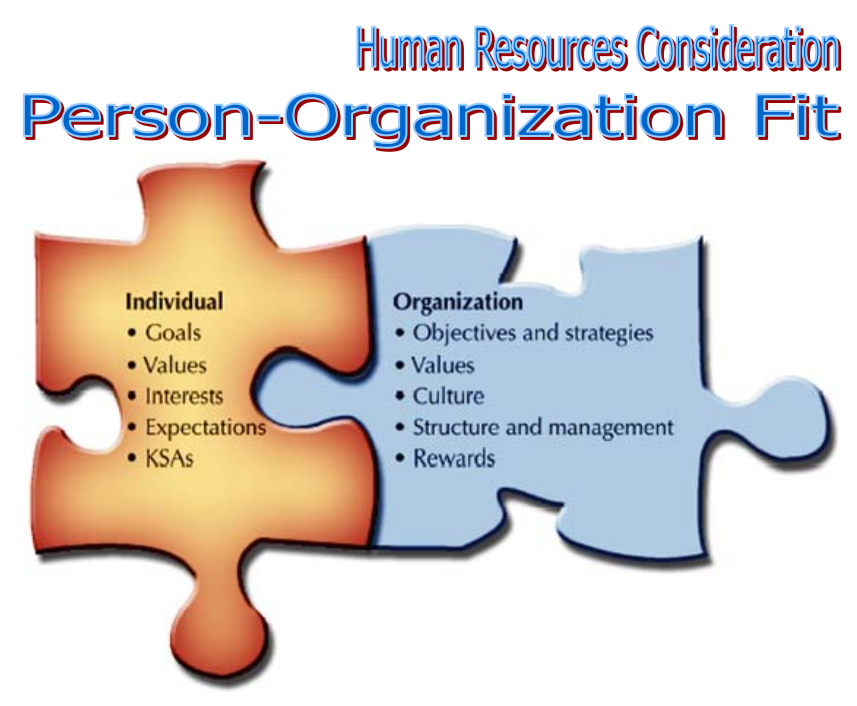

Gambar 6 Person - Organization Fit

Gambar 6 mencerminkan bagaimana kesiapan dan kecocokkan antara individu dan organisasi di dalam menjalankan roda operasional dan kinerja yang dihasilkan sangat terkait dan berkesinambungan. Untuk itu kesamaan Visi, misi, tujuan dan sasaran dari individu dengan organisasi harus terjalin dengan baik. Disintegrasi yang terjadi antara individu dan organisasi akan berdampak pada penurunan kinerja dan produktifitas organisasi secara keseluruhan. Adapun bentuk-bentuk 
disintegrasi yang terjadi berupa perubahan sasaran, nilai-nilai, kepentingan, harapan dan kinerja, hal ini akan menyebabkan sasaran strategis, nilai dan budaya perusahaan akan bertolak belakang dan secara keseluruhan perusahaan menjadi tidak sehat. Terutama bila nilai-nilai dari misi organisasi sudah tidak sejalan dengan nilai yang dimiliki oleh individu yang ada di dalam organisasi.

\section{Aspek Perubahan Dengan Adanya IT}

Bila kita melihat gambar dibawah ini merupakan suatu anekdot bahwa penggunaan e-mail di suatu perusahaan tidak melalui suatu proses perubahan secara maksimal, sehingga tingkat kepercayaan pemakai terhadap informasi yang digunakan dalam berkomunikasi menjadi tidak tepat guna. Mengapa hal tersebut bisa terjadi? Perubahan yang terjadi tidak diiringi dengan sosialisasi akan tujuan dari penggunaan IT yang dalam hal ini e-mail tidak secara jelas dan tepat sasaran ke pemakai. Untuk itu perlu dilakukan suatu evaluasi atau penilaian terhadap kemampuan pemakai terlebih dahulu sebelum dilakukan implementasi.

Kunci utama dari semua bentuk komunikasi dalam bentuk e-mail adalah untuk membantu dan mendokumentasikan setiap proses informasi yang efektif dan komunikatif di dalam dan di luar organisasi. Manfaat e-mail di dalam membantu proses kerja telah memberikan perubahan perilaku dan cara pandang para pemakai tentang bentuk komunikasi yang efektif.

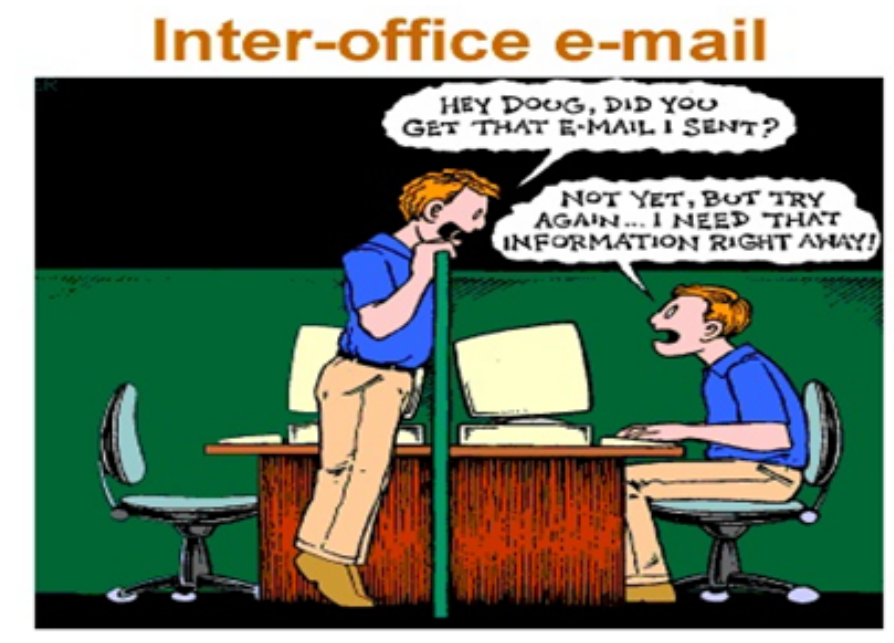

Gambar 7 Inter - office e-mail behavior

Memang tidak mudah dalam melakukan suatu evaluasi atau penilaian terhadap pemakai atau user. Tingkat kecenderungan untuk menolak akan tinggi bila kemampuan dari pemakai atau user itu sendiri masih kurang dan tidak mau belajar secara intensif. Peranan manajemen dalam memberikan arahan dan dukungan menjadi sangat penting untuk menunjang kesuksesan dari implementasi IT di suatu organisasi atau perusahaan.

\section{Peranan Manajer dan Agen Perubah}

Genius is one percent of the inspirations and 99\% is effort, and nothing can be compared with persistence and working hard, (Thomas A. Edison).

Kita perlu berubah karena dorongan kebutuhan atau keinginan? Setiap organisasi melakukan perubahan karena dorongan dari kebutuhan untuk bisa berkompetisi dan bersaing di dalam pasar global. Hal ini tidak dapat dipungkiri lagi, bahwa kebutuhan tersebut menjadi sangat esensial bagi setiap organisasi. Jika kita melihat suatu organisasi sebagai suatu Enterprise Resources, maka peranan 
pengelolaan dari para manager yang sebagai leader atau pimpinan untuk memanfaatkan sumber daya yang ada terdiri atas 4-M yaitu Man, Material, Machine dan Money serta sekarang ini dibutuhkan juga Information sebagai penggerak dari roda proses pendukung bisnis di dalam suatu organisasi. Mengapa demikian?

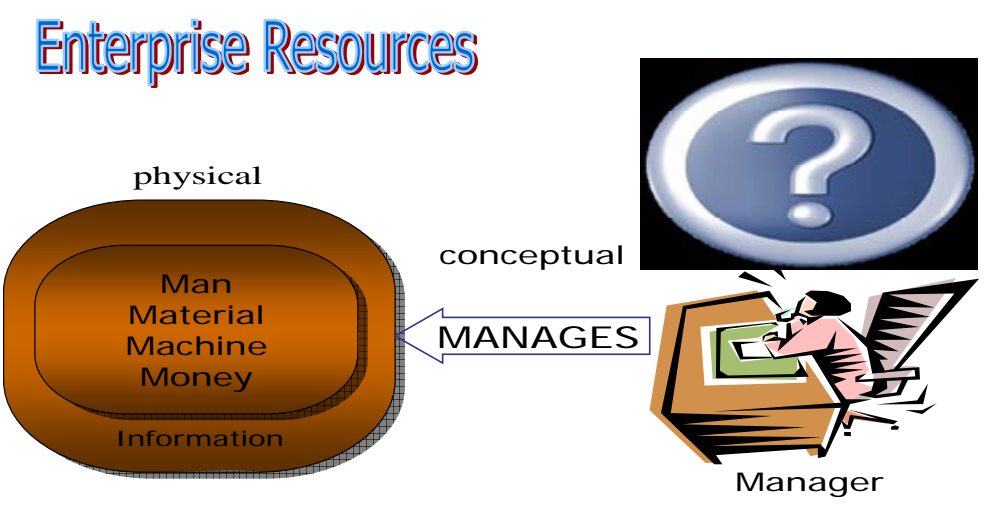

Gambar 8 Enterprise Resources

Hal ini menjadi suatu dorongan utama bagi setiap organisasi untuk dapat mengkaji ulang bagaimana pengelolaan informasi tersebut menjadi sangat kritikal bagi suatu organisasi atau perusahaan. Perlunya Information Technology agar dapat mengelola informasi menjadi suatu asset bagi manajemen puncak di dalam mengembangkan bisnisnya menjadi sangat vital dewasa ini. Banyak contoh bahwa beberapa perusahaan-perusahaan besar dan asing yang mengelola bisnisnya dengan didukung oleh pemanfaatan IT yang tepat guna telah memperoleh keuntungan secara kompetitif dalam persaingan global.

Seperti digambarkan dalam ilustrasi Gambar 9 bahwa peranan komitmen dari manajemen dalam memberikan arahan dan dukungan sangat memegang kunci utama atas sukses atau tidaknya suatu perubahan dengan pemanfaatan teknologi informasi. Untuk itu peranan tenaga IT tidak hanya handal dalam penggunaan teknologi tetapi juga harus dapat menjual konsep teknologi tersebut ke pemakai sehingga pemakai menjadi mengerti dan kemudian mau menggunakan teknologi tersebut dalam melakukan aktivitas proses bisnis di dalam organisasi atau perusahaan.

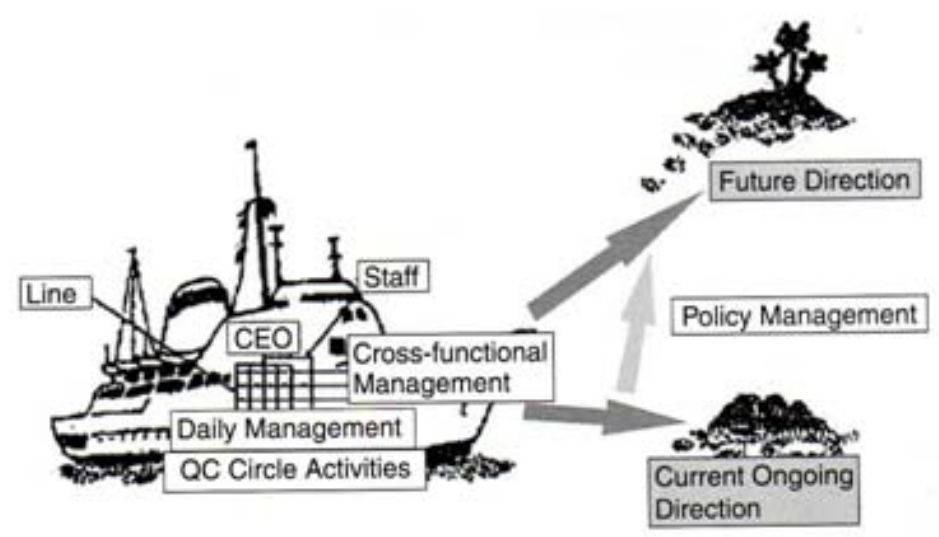

Figure 3 TQM Vehicle-Boat Model

Gambar 9 TQM and Organizational Model - Boat Model 


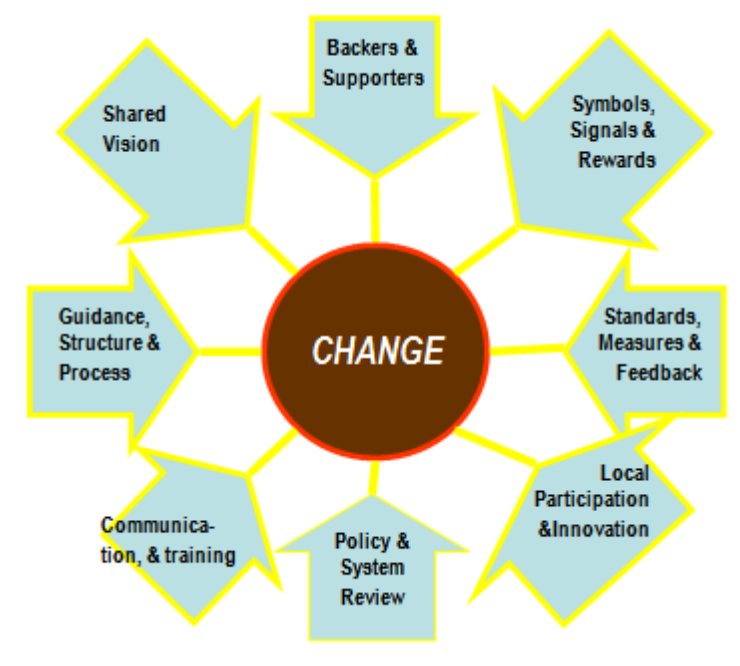

Gambar 10 Change aspects

Tentunya untuk setiap langkah perubahan dengan memanfaatkan teknologi informasi harus bisa dibuat suatu parameter atau pengukuran yang jelas sehingga target yang dicapai dapat terrealisasi dan dievaluasi secara obyektif. Gambar diatas ini menjelaskan beberapa aspek yang terkait dengan perubahan atau change itu sendiri. Sesungguhnya setiap perubahan akan dan sangat terpengaruh dari berbagai aspek yang saling terkait. Berikut ini adalah uraian yang menjelaskan beberapa aspek yang terkait yang meliputi share visions; guidance, structure and process; communications, educations and training; policy and system review; local participations and innovations; standards, measures and feedback; symbol, signals and rewards; backers and supporters.

Setiap organisasi atau perusahaan layaknya memiliki suatu visi dan misi yang jelas agar dapat menjadi arahan dan pedoman yang jelas di dalam menyusun suatu strategi organisasi maupun perusahaan. Terkadang visi dan misi yang jelas saja belumlah cukup, share visions disini mempunyai maksud mengenai bagaimana di dalam organisasi, manajemen puncak dapat berbagi informasi dan menjelaskan makna serta maksud dari visi perusahaan tersebut secara nyata dan jelas ke karyawannya, hal ini sangat penting mengingat visi tersebut dapat menjadi acuan bagi para eksekutif tentang bagaimana menyusun strategi bisnis yang dapat didukung oleh teknologi informasi sebagai perangkat pendukung. Visi yang jelas tersebut menjadi suatu landasan dan pedoman atau guidance, structure and process. Tanpa guidance, structure and process yang jelas akan cukup sulit bagi manajemen level menengah untuk menerapakan apa yang ingin dicapai di dalam suatu organisasi secara real. Tentunya setiap guidance, structure and process haruslah disosialisasikan secara berkala dan terarah, karena proses sosialisasi tersebut memegang peranan penting. Untuk itu peranan communications, educations and training, menjadi ukuran bagaimana perubahan di dalam organisasi dapat menjadi efektif atau tidak dengan bantuan Teknologi Informasi. Komunikasi yang efektif di setiap bagian atau departemen serta lintas departemen menjadi kunci dalam proses pembelajaran dan pelatihan secara berkesinambungan. Kekuatan ketiga komponen tersebut akan mempertinggi tingkat kesuksesan dari implementasi Teknologi informasi di dalam suatu organisasi atau perusahaan.

Dengan terimplementasinya Teknologi informasi bukan berarti suatu organisasi menjadi statis atau kaku. Peranan agen perubah di setiap departemen dan sistem koordinasi yang baik akan memberikan suatu masukkan untuk perbaikan dari policy and system review. Mengapa hal ini perlu dilakukan ? Karena perubahan yang terjadi harus selalu dikaji dari sisi positif dan negatifnya sehingga evaluasi policy and system review secara berkala akan memberikan dampak yang positif untuk pengembangan organisasi di masa mendatang. Pengembangan bisnis dari organisasi atau perusahaan menjadi sangat efektif dan juga keterlibatan dari local participations and innovations dari setiap individu di dalam organisasi akan memberikan dampak kemajuan dalam memberikan kontribusi 
kepada perusahaan. Memang tidak mudah bahwa perubahan yang terjadi akan memberikan kontribusi positif, tetapi proses yang berkesinambungan akan mewujudkan suatu standards, measures and feedback yang efektif dan efisien. Dengan standar, pengukuran dan umpan balik yang jelas akan mewujudkan suatu symbol, signals and rewards di dalam organisasi atau perusahaan. Ciri khas inilah yang akan menjadi suatu budaya di dalam organisasi yang membuat suatu organisasi menjadi lebih dinamis serta penghargaan atas ide atau inovasi dari individu atau team yang ada akan memberikan dampak luas terhadap pengembangan bisnis perusahaan serta dapat berkompetisi di dalam pasar global. Bila kita lihat siklus yang terjadi dari perubahan yang diharapkan tentunya akan memberikan suatu dukungan yang berkesinambungan dalam bentuk backers and supporters bagi organisasi atau perusahaan. Perusahaan atau organisasi yang ingin maju dan sehat tentunya harus selalu melakukan suatu diagnosa secara mendalam, kita dapat mengamati bahwa siklus perubahan seperti dalam gambar diatas terjadi dan berlangsung sangat efektif, hanya saja waktu yang dibutuhkan oleh setiap organisasi atau perusahaan sangatlah bervariasi dan tidak sama. Hal ini sangat bergantung dari kemampuan agen perubah dari level atas sampai menengah untuk menggerakkan perubahan dengan bantuan teknologi informasi untuk meningkatkan kinerja perusahaan secara terus menerus. Dari sisi perubahan itu sendiri bila kita telaah lebih jauh kita dapat mengukur dan bagi atas 2 kelompok yaitu perubahan yang bersifat taktis dan strategis.

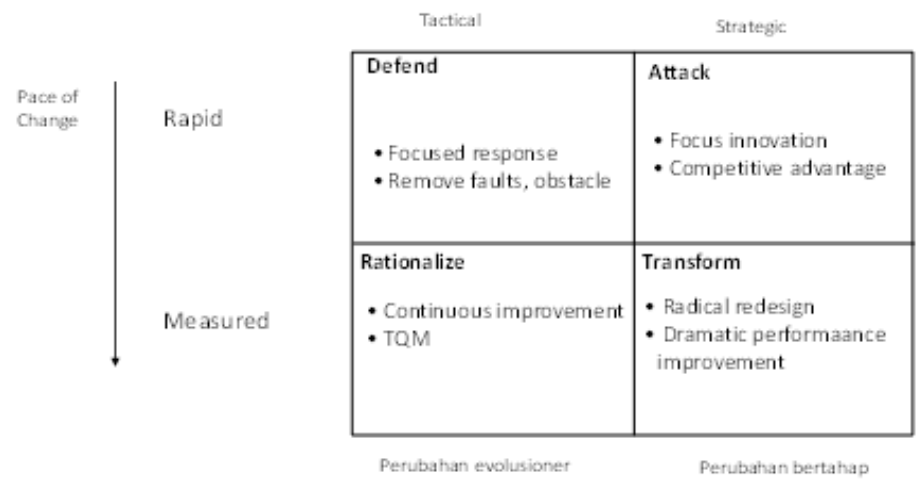

Gambar 11 Pengukuran dan Akselerasi dari Perubahan.

\section{Taktis}

Sering perubahan ini bersifat evolusioner dan dibagi atas 2 strategi bila dilihat dari kecepatan perubahan yaitu defend dan rationalize. Kondisi perubahan dikatakan bersifat defend bila dilakukan ketika organisasi atau perusahaan berusaha untuk fokus terhadap respon yang terjadi dari individu yang menerima dampak atas perubahan tersebut, kondisi bertahan dalam wujud penolakan yang ada di dalam organisasi. Perubahan ini bersifat cepat dan berusaha menggurangi tingkat kesalahan dan hambatan yang terjadi di dalam organisasi. Proses pengukurannya pun cukup sulit dan cenderung pengukuran secara kuantitatif sulit untuk dicapai. Sedangkan proses perubahan secara rationalize yaitu perubahan yang lebih terukur dengan melalui tahapan secara berkesinambungan dan membutuhkan waktu yang lebih lama. Umumnya organisasi menerapakan suatu continuous improvement atau di perusahaan-perusahaan Jepang mereka menerapkan Kaizen dan TQM yang dijalankan secara formal dan terfokus dalam waktu yang lama serta terencana. Penerapan secara taktis diatas akan memberikan dampak terhadap suatu evolusi perubahan di dalam organisasi atau perusahaan.

\section{Strategis}

Strategis yaitu perubahan yang bersifat bertahap dan dibagi atas 2 jenis yaitu attack dan transform. Strategi attack secara cepat dilakukan ketika berfokus pada inovasi dan berusaha untuk mencapai suatu tingkat keunggulan secara kompetitif di dalam persaingan secara global. Hal ini juga 
memiliki tingkat resiko yang cukup tinggi. Perubahan ini cenderung bersifat cepat dan responsif terhadap individu atau team di dalam organisasi. Sedangkan untuk Strategi transform dilakukan melalui suatu perubahan secara radikal, bertahap dan terukur nyata dimana perubahan yang terjadi di dalam organisasi diatur sedemikian rupa sehingga proses dan personil yang terkait berubah secara total meskipun melalui suatu tahapan-tahapan yang sistematis. Yang menjadi pertanyaan utama bagi kita adalah kapan kita melakukan dan memanfaatkan strategi yang tepat untuk perubahan itu sendiri ? Peranan seorang agen perubah dan manajemen puncak untuk melakukan evaluasi terhadap kondisi organisasi dan perusahaan sangat penting untuk memilih dan mengkombinasikan secara tepat dan pada waktu yang tepat. Keahlian inilah yang menjadi kunci utama bagi manajemen puncak di dalam memilih seorang agen perubah atau team perubah yang akan menjalankan suatu misi perubahan dengan bantuan teknologi informasi sebagai perangkat pembantu.

\section{PENUTUP}

Dengan memahami setiap aspek perubahan yang terjadi dari adanya Implementasi IT, tentunya akan memberikan suatu dinamika di dalam suatu organisasi. Antisipasi dan kolaborasi dalam menghadapi dan menyikapi setiap perubahan tentunya harus dipersiapkan dengan baik dan harus dikomunikasikan secara berkala. Banyak implementasi IT yang tidak diantisipasi dengan baik dari sisi komunikasi akan berdampak pada kegagalan yang tidak sedikit. Pimpinan puncak juga harus melihat aspek psikologi dan keuangan secara terintegrasi sehingga perencanaan yang lebih mantap dapat memberikan manfaat yang optimal dari setiap implementasi IT.

\section{DAFTAR PUSTAKA}

Abrahamson, E. (2004). Change without Pain. Harvard Business School Press.

Day, J. G. (1996). An Executive’s Guide to measuring I/S. Strategic and Leadership, Wincite System.

Hesselbein, F., Goldsmith, M., \& Beckhard, R. (Eds). (1997). The Organization of the Future. JoseyBass.

Harrington, H. J., Esseling, E. K. C., \& Harm, V. N. (1997). Business Process Improvement Workbook. McGraw Hill.

Malhotra, Y., \& Galetta, D. F. (2004). Building System that User Want to Use. Communications of the ACM, December 2004/Vol 47 No. 12.

Teng, M. (2002). Corporate Turnaround, Nursing a Sick Company back to Health. Singapore: Prentice-Hall.

Turbide, D. A. (2005). Five Ways ERP Can Help You Implement Lean. EPICOR Software Corporations.

Widjaya, I. K. (2006). Mengapa perlu Best Practice dalam Penerapan Teknologi Informasi. Jurnal Komputer dan Informatika, Fakultas Teknologi Informasi Universitas Tarumanegara, VOL 7 No. 1 (2006) Page 29 - 36.

Widjaya, I. K. (2006). Bagaimana Mengatasi Perubahan dengan Adanya Information Technology. Jurnal INFOTEK Dharma Putra, Jurusan Teknologi Informasi STMIK Dharmaputra, VOL 1 No. 2 (2006) Page 89 - 97. 